\title{
BERBAGAI MANFAAT DAUN BIDARA (ZIZIPHUS MAURITIANA LAMK) BAGI KESEHATAN DI INDONESIA
}

\author{
Maulana Siregar \\ Divisi Ilmu Kedokteran Islam, Fakultas Kedokteran, Universitas Muhammadiyah Sumatera Utara \\ Email: maulana.srg25@gmail.com
}

\begin{abstract}
Abstrak
Pendahuluan: Khasiat daun bidara (Ziziphus mauritiana Lamk) telah disebutkan dalam Al-Quran dan Hadist Nabi Muhammad SAW,Studi meta analisis ini bertujuan untuk mengetahui berbagai manfaat daun bidara (Ziziphus mauritiana Lamk) yang telah dibuktikan secara ilmiah melalui penelitian di Indonesia. Metode: Melakukan penelusuran literatur menggunakan aplikasi Google Scholar dan melalukan analisis terhadap literatur yang masuk dalam kriteria inklusi. Hasil: Dari hasil penelusuran ditemukan 22 artikel dan hasil penelitian yang menyimpulkan tentang maanfaat daun bidara. Kesimpulan: Manfaat terbesar daun bidara adalah sebagai antimikroba, selain itu juga terdapat banyak manfaat lain seperti analgetik antipiretik dan antiinflamasi, antikanker, serta dalam berfungsi sebagai pelindung sel-sel tubuh seperti ginjal, hati dan otak.
\end{abstract}

Kata kunci: Bidara

(c) $\mathrm{EY}$ This work is licensed under a Creative Commons Attribution 3.0 License.

\section{PENDAHULUAN}

Daun tanaman bidara (Ziziphus mauritiana Lamk) merupkan salah satu tanaman yang disebutkan dalam Al-Quran banyak disebutkan dalam hadist-hadist Nabi Muhammad SAW, Dalam Al-Quran tanaman bidara disebutkan sebagai tanaman sidr, hal ini disebutkan dalam surah As-Saba ayat 16 yang artinya "Tetapi mereka berpaling, Maka Kami datangkan kepada mereka banjir yang besar dan Kami ganti kedua kebun mereka dengan dua kebun yang ditumbuhi (pohon-pohon) yang berbuah pahit, pohon Atsl dan sedikit dari pohon Sidr". "Dalam beberapa hadist Nabi Muhammad SAW di sebutkan beberapa anjuran penggunaan daun bidara dalam

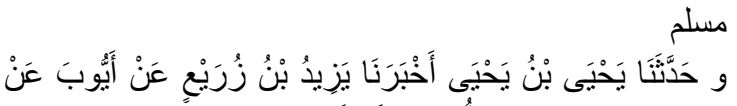

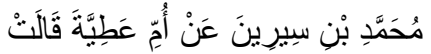

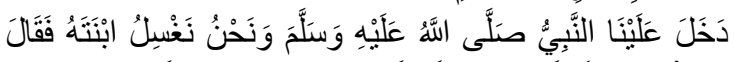

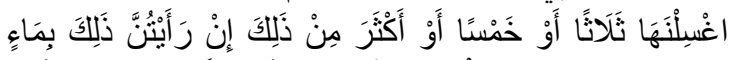

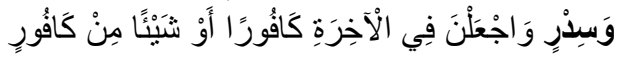

yang artinya: "Mandikanlah dengan mengguyurkan air yang dicampur dengan daun bidara tiga kali, lima kali atau lebih dari itu jika kalian anggap perlu dan jadikanlah yang terakhirnya dengan kafur barus (wewangian)". 2

Dalam hadist HR. Bukhari no. 314 dan Muslim no. 332 Yang berbunyi: HR. Bukhari no. 1253 dan Muslim no. 939 


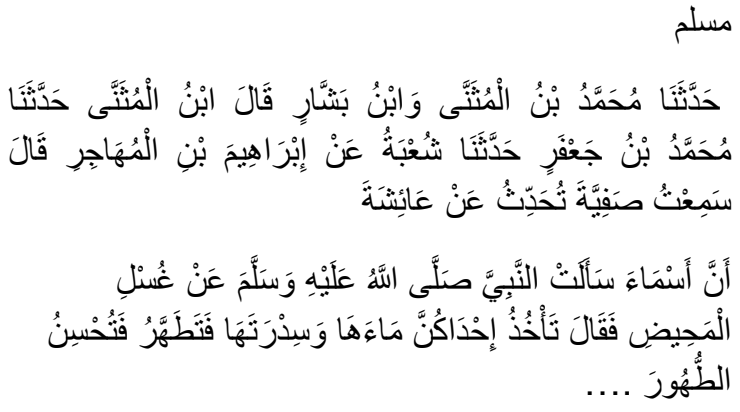

Yang artinya:

"Dari Aisyah radhiallahu 'anha bahwa "Asma' bertanya kepada Nabi shallallahu 'alaihi wa sallam tentang mandi wanita haidh. Maka beliau bersabda, "Salah seorang dari kalian hendaklah mengambil air dan daun bidara, lalu engkau bersuci, lalu membaguskan bersucinya....".3

Dari firman dan hadist tersebut tersirat bahwa daun bidara memiliki manfaatmanfaat tertentu. Sementara dalam beberapa penelitian disebutkan beberapa manfaat daun bidara diantaranya sebagai antimikroba, antikanker, antidibetik, inflamasi. Studi meta analisis ini bertujuan untuk mengetahui berbagai manfaat dari daun bidara di Indonesia.

\section{METODE PENELITIAN}

Penelusuran literatur dilakukan dengan menggunakan aplikasi google scholar, literatur yang masuk kriteria inklusi adalah (a) Memiliki judul penelitian yang membahas tentang daun bidara, (b) Penelitian dilakukan di Indonesia, (c) Literatur memiliki identitas penulis yang jelas dan berasal dari institusi yang jelas. (d) Memiliki tahun penelitian dan tahun publikasi yang jelas, (e) Dipublikasinya melalui jurnal nasional ber ISSN atau masuk dalam repository lembaga pendidikan yang jelas. (f) Memiliki metode penelitian, (g) Memiliki diskusi dengan referensi yang jelas, (h) Memiliki daftar pustaka yang jelas.
Literatur yang berhasil dikumpulkan selanjutnya dibaca dan dianalisis hasil penelitiannya, selanjutnya manfaat daun bidara yang terdentifikasi di kelompokkan dalam tabel menggunakan aplikasi Microsoft Exel dan dianalisis jumlah dan persentasinya.

\section{HASIL}

Dari hasil penelusuran literatur didapatkan 22 artikel dan karya tulis ilmiah (Tabel 1). Dari hasil analisis literatur maka peneliti menjumpai beberapa manfaat daun bidara seperti yang tertuang dalam gambar 1 dan gambar 2 .

\section{DISKUSI}

\section{Anti Mikroba}

Berdasarkan grafik 1 dan 2 terlihat bahwa manfaat daun bidara terbanyak adalah sebagai antimikroba, baik bakteri, jamur mau pun parasit. Beberapa zat aktif yang terkandung dalam ektrak daun bidara yang menunjukkan potensi tersebut adalah alkaloid, flavanoid, tanin fenol dan saponi. ${ }^{6}$

Dalam uji daya hambat terhadap ektrak etanol daun bidara didapatkan adanya zona hambat pada berbagai jenis spesies bakteri yaitu Pseudomonas aeruginosa, Salmonella thypi, Echerichia coli, Staphylococcus epidermidis, Streptococcus mutans, Vibrio sp. ${ }^{6}$ Salah satu kandungan aktif daun bidara yang berfungsi sebagai antibakteri adalah saponin. Saponin merupakan glikosida komplek, saponin yang berasal dari bahasa latin yaitu " sapo" artinya sabun, senyawa ini bersifat polar dan larut dalam air (hidrofilik) dan sering disering juga disebut surfaktan alamiah karena dapat menurunkan tegangan permukaan., 8,17 Kandungan lain seperti alkaloid, flavonoid dan tanin juga menunjukan aktivitas antimikroba, mekanisme antimikroba alkaloid adalah mengganggu komponen 
petidoglikan pada bakteri sehingga lapisan dinding sel mikroba tidak lagi terbetuk secara untuk hal ini menyebabkan sel mikroba menjadi mudah lisis. ${ }^{5}$ Flavanoid bekerja membetuk senyawa komplek dengan protein ektraseluler dan terlarut yang dapat merusak membran sel mikroba, sementara tanin memiliki kemampuan untuk menciutkan dinding sel sehingga mengganggu permeabilitas sel mikroba yang mengganggu aktivitas tranport zat selular pada bakteri. ${ }^{5,25}$

Tabel 1. Daftar Artikel yang Relevan

\begin{tabular}{|c|c|c|}
\hline No & Penulis & Manfaat \\
\hline 1. & Agustina $\mathrm{R}^{4}$ & Anagetik \\
\hline 2. & Agustina $\mathrm{W}^{5}$ & Antibakteri \\
\hline 3. & Ashri $\mathrm{NH}^{6}$ & Antibakteri \\
\hline 4. & Bintoro $\mathrm{A}^{7}$ & Identifikasi saponin \\
\hline 5. & Chairunnisa $^{8}$ & Antimikroba, antiinflamasi \\
\hline 6. & Ekanursyahfitri $^{9}$ & Antibakteri \\
\hline 7. & Fatimah $\mathrm{DN}^{10}$ & Neuroprotektor \\
\hline 8. & Haeria $^{11}$ & Antioksidan \\
\hline 9. & Jannah $^{12}$ & Antikanker \\
\hline 10. & Kamila $\mathrm{K}^{13}$ & Antibakteri \\
\hline 11. & Kartikawati $\mathrm{H}^{14}$ & Antibakteri \\
\hline 12. & Kisdjamiatun $^{15}$ & Anti Diabetik \\
\hline 13. & Komaruddin $^{16}$ & Pengawet Daging \\
\hline 14. & Lumban Raja IM"1' & Anti Mikroba \\
\hline 15. & Maulana $\mathrm{M}^{18}$ & Kandungan Berkhasiat \\
\hline 16. & Novia $^{19}$ & Anti Depresan \\
\hline 17. & Noviasari $\mathrm{RW}^{20}$ & Anti Oksidan, Anti Diabetik \\
\hline 18. & Nugrahwati $F^{21}$ & Anti Piretik \\
\hline 19. & Putri RAZ $Z^{22}$ & Anti Kanker \\
\hline 20. & Rahmawati $Y^{233}$ & $\begin{array}{l}\text { Anti Oksidan, Antibakteri, Anti } \\
\text { Inflamasi }\end{array}$ \\
\hline 21. & Sudaryanto ${ }^{24}$ & Hepato Protektor \\
\hline 22. & Taufiq $^{2 b}$ & Anti Mikroba \\
\hline
\end{tabular}




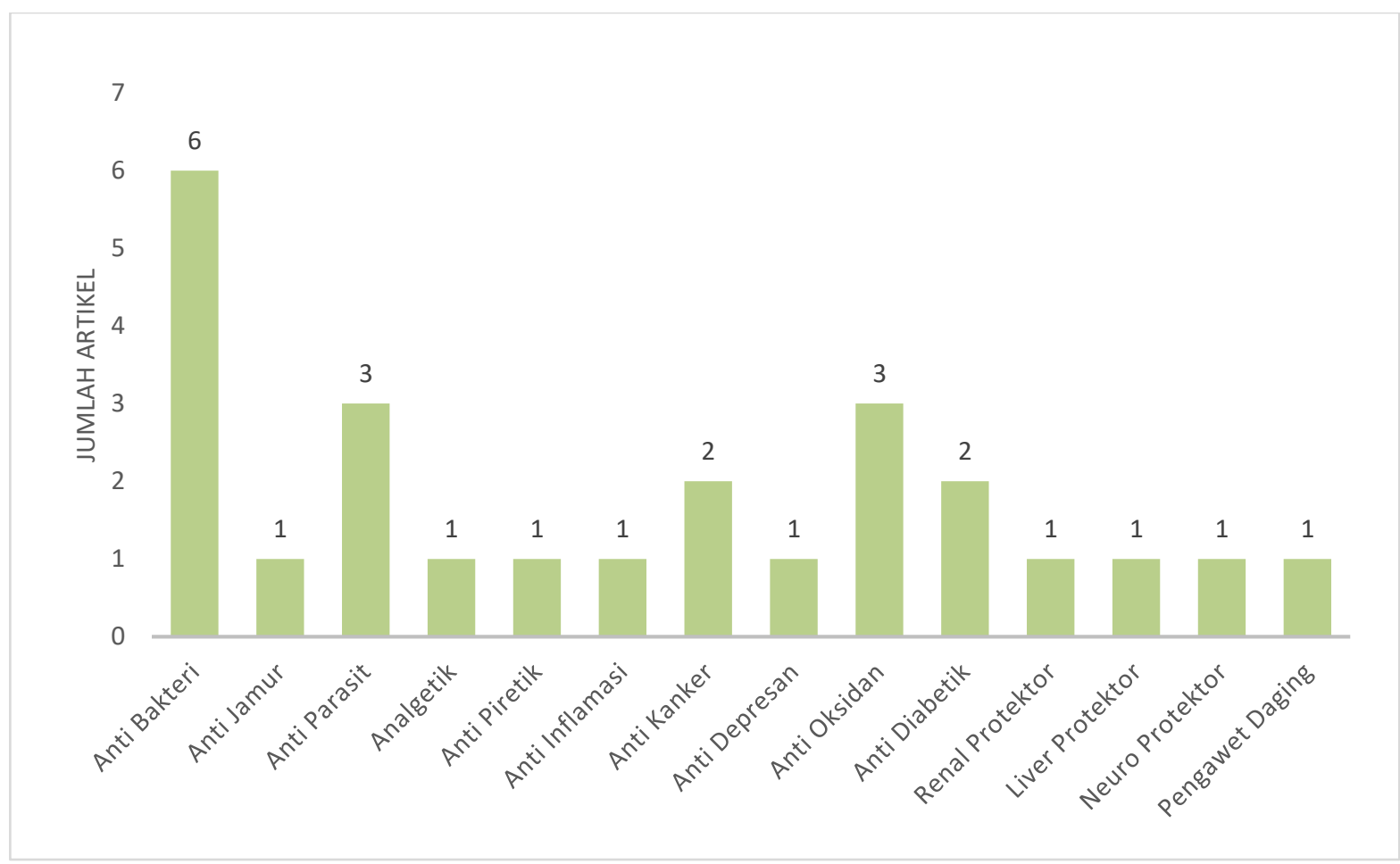

Gambar 1. Jumlah artikel yang menjelaskan berbagai manfaat daun bidara.

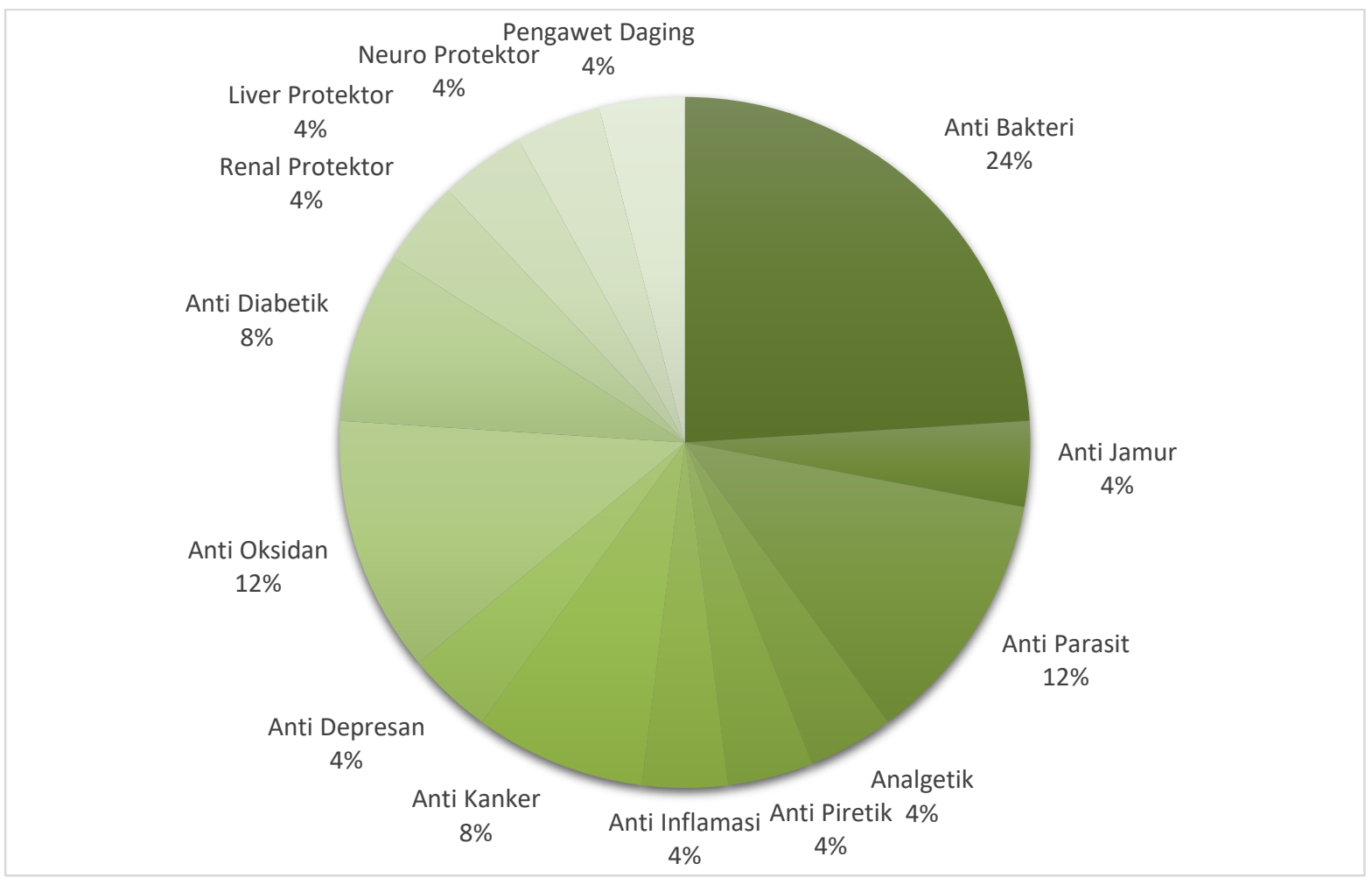

Gambar 2. Persentasi berbagai manfaat daun bidara 
Berdasarkan hasil penelitian diatas dapat memberikan penjelasan ilmiah kepada kita tentang pembuktian kebenaran hadist Nabi Muhammad SAW 14 abad yang lalu yang menganjurkan penggunaan daun bidara untuk kegiatan seperti bersuci, hal tersebut terdapat pada (HR. Bukhari no. 1253 dan Muslim no. 939) yang berbunyi "Mandikanlah dengan mengguyurkan air yang dicampur dengan daun bidara tiga kali, lima kali atau lebih dari itu jika kalian anggap perlu dan jadikanlah yang terakhirnya dengan kafur barus (wewangian)." Dan (HR. Bukhari no. 314 dan Muslim no. 332) yang berbunyi "Dari Aisyah radhiallahu 'anha bahwa "Asma' bertanya kepada Nabi shallallahu 'alaihi wa sallam tentang mandi wanita haidh. Maka beliau bersabda, "Salah seorang dari kalian hendaklah mengambil air dan daun bidara, lalu engkau bersuci, lalu membaguskan bersucinya....".2

\section{Analgetik, Antipiretik dan Antiinflamasi}

Khasiat sebagai analgetika antipiretik daun bidara akibat kandungan plavanoid yang bekerja melalui dua mekanisme dalam mengambat faktor peradangan. Mekanisme pertama dengan menghambat enzim siklooksigenase yang mengakibatkan pembentukan prostaglandin sebagai salah satu mediator timbulnya nyeri dan demam tidak terjadi, mekanisme kedua dengan hambatan terhadap degranulasi netrofil yang berakibat penghambatan pelepasan sitokin, radikal bebas serta enzim yang berperan pada proses inflamasi. ${ }^{4,21,23}$

\section{Anti Kanker}

Penelitian terhadap fraksi $\mathrm{n}$ heksana dan etanol daun bidara menemukan adanya senyawa alkaloid, saponin, triterpenoid dan steroid yang memiliki efek sitotoksik sebagai antikanker dimana diketahui bahwa senyawasenyawa tersebut menghasilkan senyawa reduksi yang dikenal dengan nama kuersetin . Kuersetin yang tergolong antioksidan ini memiliki aktivitas terhadap reseptor proto-onkogen proteintirosin kinase dan uridin 5-monofosfat sintase.
Sebagai reseptor obat-obatan antikaner yang pada akhirnya dapat melakukan inhibisi terhadap DNA topoisomerase pada sel kanker yang berakibat penghambatan pertumbuhan sel kanker. ${ }^{12,22,26}$

\section{Anti Depresan}

Khasiat sebagai antidepresan pada daun bidara akibat kandungan alkaloid dan plavanoid yang mampu menghambat kerja dari mono-aminoksidase sehingga menghambat degradasi neurotransmiter syaraf pusat seperti serotonin dan katekolamin yang efeknya pada otak menimbulkan potensi stimulasi susunan saraf pusat yang menghambat terjadinya depresi. ${ }^{19,27}$

\section{Anti Oksidan}

Penelitian yang dilakukan oleh Haeria (2016) menyimpulkan bahwa ektrak daun bidara memiliki aktivitas antioksidan yang kuat, hal ini berkat kandungan plavanoid yang terkandung di dalamnya. Plavanoid merupakan senyawa pereduksi yang dapat menghambat banyak reaksi oksidasi dengan cara mentransfer senyawa elektron pada senyawa radikal bebas sehingga senyawa radikal bebas menjadi stabil dan tidak terjadi reaksi oksidasi. Hasil penelitian diperoleh kadar flavonoid total dari ektrak etanol daun bidara sebesar $1,5312 \%$ dan memiliki aktivitas antioksidan kuat dengan nilai IC50 sebesar 90,9584, dimana secara spesifik suatu senyawa dikatakan sebagai antioksidan sangat kuat untuk IC50 bernilai 50 ppm, kuat untuk 50-100 ppm, sedang untuk 101-150 ppm dan lemah untuk IC50 > 150 ppm. 11,23 Penelitian lain yang dilakukan oleh Noviasari RW menunjukkan bahwa aktivitas antioksidan daun bidara lebih tinggi dibandingkan dengan vitamin $\mathrm{C}^{20}$

\section{Anti Diabetik}

Aktivitas antidiabetik ekstrak daun bidara diperoleh melalui mekanisme penghambatan enzim-enzim pemecah 
karbohidrat menjadi glukosa yang terdapat di saluran cerna, dua golongan enzim yang dihambat ialah $\alpha$-Amilase dan $\alpha$ - Glukosidase. Golongan enzim $\alpha$ Amilase diproduksi oleh kelenjar saliva dan pankreas yang fungsi utamanya adalah memecah amilum (amilase saliva) dan memecah glikogen (amilase pankreas), penghambatan aktivitasnya akan menghambat pemecahan karbohidrat di saluran cerna dan dalam tubuh serhingga mempengaruhi ketersedian glukosa dalam plasma darah. Golongan a- Glukosidase didalamnya terdapat maltase, isomaltase, glukomaltase, dan sukrase memiliki fungsi menghidrolisis oligosakarida yang masuk ke usus halus sehingga apabila dihambat akan mempengaruhi pencernaan karbohidrat dan absorbsinya sehingga dapat mencegah peningkatan kadar glukosa darah setelah makan . 15,20,28

\section{Renal Protektor, Liver Protektor dan Neuro Protektor}

Sifat proteksi terhadap berbagai sel tubuh oleh ekstrak daun bidara diyakini akibat kandungan saponin, tanin, alkaloid dan plavanoid yang bekerja menghambat pembetukan ROS dan protein amiloid $\beta$ yang bertanggung jawab terhadap kerusakan mikrovakular akibat adanya respon inflamasi. ${ }^{10,14,24}$

\section{Pengawet Daging}

Pemanfaatan daun bidara yang memiliki khasiat sebagai antimikroba dapat juga dimanfaatkan sebagai pengawet daging alamiah, hal ini akibat aktivitas fenolat dan plavanoid yang terdapat didalam nya yang mampun merusak dinding sel bakteri. ${ }^{16}$

\section{KESIMPULAN}

Dari hasil penelusuran dan analisis literatur dapat disimpulkan bahwa daun bidara memiliki banyak manfaat. Manfaat terbesar daun bidara adalah sebagai antimikroba, selain itu juga terdapat banyak manfaat lain seperti analgetik antipiretik dan antiinflamasi, antikanker, serta dalam berfungsi sebagai pelindung sel-sel tubuh seperti ginjal, hati dan otak.

\section{REFERENSI}

1. Al-Quran,As-Saba;16

2. Muhammad SAW.

3. Muhammad SAW.

4. Agustina R.Uji aktivitas analgesik ektrak daun bidara (Ziziphus mauritiana Lamk) terhadap mencit putih jantan (Mus musculus) dengan metode writhing test [skripsi]. Repository Universitas Setia Budi. November 2019.

5. Agustina W. Uji aktivitas antibakteri ekstrak etanol, Fraksi n-Heksana, Etil Asetat, dan air dari daun bidara (Ziziphus mauritiana Lamk) terhadap Salmonella typhi ATCC 13311 [skripsi]. Repository Universitas Setia Budi. Februari 2019.

6. Ashri NH. Uji aktivitas dan identifikasi senyawa kimia antibakteri ektrak etanol daun bidara (Ziziphus spina-christi L) terhadap beberapa bakteri patogen [skripsi]. Repository UIN Alauddin Makasar. Oktober 2017.

7. Bintoro A, Ibrahim AM, Situmeang B. Analisis dan indentifikasi senyawa saponin dari daun bidara (Ziziphus mauritiana Lamk). Jurnal ITEKIMIA. Agustus 2017;2(1):84-94.

8. Chairunnisa $S$, Wartini NM, Suhendra L. Pengaruh suhu dan waktu maserasi terhadap karakteristik ektrak daun bidara (Ziziphus mauritiana Lamk) sebagai sumber saponin. Jurnal Rekayasa dan Manajemen Agroindustri.Desember 2019;7(4):551-60.

9. Ekanursyahfitri. Mutu fisik dan aktivitas terhadap bakteri Staphylococcus aureus sediaan masker gel-peel off ektrak daun bidara (Ziziphus mauritiana Lamk) sebagai antijerawat [skripsi]. Repository Akademi Farmasi Putera Indonesia Malang. Juli 2019.

10. Fatimah DN. Pengaruh ekstrak daun bidara (Ziziphus mauritiana Lamk) dalam mencegah penurunan skor memori pada tikus strain wistar model hipetensi [skripsi]. Repository Universitas Muhammadiyah Malang. Juli 2019. 
11. Haeria, Hermawati, Pine ATUD. Penentuan kadar flavonoid total dan aktivitas antioksidan ekstrak etanol daun bidara (Ziziphus spina-christi L.). Journal of Pharmaceutical and Medical Sciences. 2016; 1(2):57-61.

12. Jannah. Uji aktivitas antikanker ekstrak dan fraksi daun bidara laut (Ziziphus mauritiana Lamk) terhadap sel kanker payudara (T47D) melalui metode MMT [skripsi].Electronic Theses Universitas Islam Negeri Maulana Malik Ibrahim Malang. April 2019.

13. Kamila K. Efektivitas ektrak tanaman bidara upas (Ziziphus spina-christi L) terhadap pengendalian bakteri Staphylococcus aureus [skripsi].Repository Universitas Pasundan. Oktober 2019.

14. Kartikawati $\mathrm{H}$, Kisdjamiatun.Pencegahan gangguan fungsi ginjal selama infeksi plasmodium berghei ANKA mencit balb/c yang diberi ekstrak daun bidara. Repository Universitas Diponegoro. Agustus 2010.

15. Kisdjamiatun,Sudaryanto, Kartikawati $\mathrm{H}$. Pengaruh tingkat parasitemia terhadap kadar glukosa darah selama infeksi plasmodium berghei ANKA pada mencit balb/c yang diberi ektrak daun bidara. Repository Universitas Diponegoro. Agustus 2010.

16. Komaruddin, Miwada MINS, Lindawati SA. Evaluasi kemampuan ektrak daun bidara (Ziziphus mauritiana Lamk) sebagai pengawet alami pada daging ayam broiler.Journal of Tropical Animal Science. Agustus 2019;7(2):899-910.

17. Lumbanraja IM, Wartini NM,Suhendra L. Pengaruh jenis pelarut dan ukuran partikel bahan terhadap karakteristik ekstrak daun bidara sebagai sumber saponin. Jurnal Rekayasa dan Manajemen Agroindustri. Desember 2019;7(4):541-550.

18. Maulana M. Profil kromatografi lapis tipis (KLT) ektrak daun bidara arab (Ziziphus spina-christ L.) berdasarkan variasi pelarut [skripsi]. Electronic Theses Universitas Islam Negeri Maulana Malik Ibrahim Malang. April 2019.

19. Novia, NPH. Uji aktivitas antidepresan ektrak daun bidara (Ziziphus mauritiana Lamk) terhadap mencit putih jantan (Mus musculus) [skripsi]. Repository Universitas Setia Budi. November 2019.
20. Noviasari RW. Uji aktivitas antioksidan dan antidiabetik dari fraksi ekstrak daun bidara upas (Merremia mammosa (Lour) Hallier f.) [skripsi]. Repository Universitas Jember. Maret 2018.

21. Nurgrahwati. Uji aktivitas antipiretik ekstrak daun bidara (Ziziphus spina-christi L) terhadap mencit jantan (Mus musculus)[skripsi]. Repository UIN Alauddin Makasar. Oktober 2017.

22. Putri RAZ. Uji aktivitas daun bidara arab (Ziziphus spina-christ L.) sebagai anti kanker pada sel kanker kolon (WiDr) melalui metode MTT dan identifikasi senyawa aktif dengan metode LC-MS [skripsi]. Electronic Theses Universitas Islam Negeri Maulana Malik Ibrahim Malang. April 2018.

23. Rahmawati Y. Uji tegangan permukaan dan aktivitas antioksidan pada ekstrak daun bidara (Ziziphus mauritiana Lamk) [thesis]. Digital Library UIN Sunan Gunung Jati. Oktober 2018.

24. Sudaryanto, Kisdjamiatun, Kartikawati $\mathrm{H}$. Pengaruh ekstrak daun bidara terhadap kadar trigliserid darah selama infeksi plasmodium berghei ANKA pada mencit balb/c. Repository Universitas Diponegoro. Agustus 2010.

25. Taufiq. Aktifitas antimikroba ektrak etanol daun bidara laut (Ziziphus mauritiana Lamk) terhadap pertumbuhan Candida albicans dan Escherichia coli. 2018; $2(1): 1-8$.

26. Ruswanto, Garna IM, Tuslinah L, Richa M, Lestari T, Nofianti T. Kuersetin: penghambat uridin 5-monofosfat sintase sebagai kandidat antikanker. Alchemy Jurnal Penelitian Kimia.September 2018;14(2):236-252.

27. Santosh P, Venugopl R, Nilakash AS, Kunjbihari S, Manggala L. Antidepressant activity of methanolic extract of passiflora foetida leaves in mice. International Journal of Pharmaceutical Science. 2011; 3(1):112-115.

28. Juge N, Svensson. Review proteinaceous inhibitor of carbohydrate active enzime in cereals: implication in agriculture, cereal processing and nutrition. Journal Science Food And Agriculture.2006;86(11):15731586. 